\title{
Analisis Faktor Produksi Terhadap Produksi, Efisiensi Dan Pendapatan Wortel Di Desa Surbakti, Kecamatan Simpang Empat, Kabupaten Karo
}

\author{
${ }^{1}$ Henrykus Sihaloho*, ${ }^{2}$ Sarah Butar-Butar \\ ${ }^{1,2}$ Program Studi Agribisnis, Fakultas Pertanian Unika Santo Thomas \\ Email : *henrykussihaloho@gmail.com
}

\begin{abstract}
Abstrak
Kecamatan Simpang Empat merupakan penghasil wortel di Kabupaten Karo. Membandingkan luas lahan dan produktivitas wortel daerah ini dengan Kecamatan Berastagi, luas lahan wortel di daerah ini 674 ha, sedangkan di Berastagi 186 ha, sementara dari segi produktivitas Berastagi jauh lebih baik (22,46 ton/ha versus 28,44 ton/ha). Penelitian ini berlokasi di Desa Surbakti, Kecamatan Simpang Empat. Berdasarkan prasurvei, faktor-faktor produksi yang digunakan di desa ini adalah bibit, pupuk kandang, pupuk Ammophos, pupuk NPK, pupuk KCL, pestisida Antracol, pestisida Gramoxone, dan tenaga kerja. Penelitian ini bertujuan menganalisis pengaruh kedelapan faktor terhadap produksi, tingkat efisiensi, dan pendapatan usahatani wortel di daerah penelitian. Temuan penelitian ini menunjukkan, secara serempak (uji F) penggunaan faktor produksi bibit, pupuk kandang, pupuk Ammophos, pupuk NPK, pupuk KCL, pestisida Antracol, pestisida Gramoxone, dan tenaga kerja berpengaruh nyata terhadap produksi usahatani wortel di daerah penelitian. Secara parsial (ujit) bibit, pupuk kandang, pupuk Ammophos, pupuk NPK, pupuk KCL, pestisida Antracol, pestisida Gramoxone, dan tenaga kerja berpengaruh nyata terhadap produksi wortel, sedangkan pupuk KCL tidak berpengaruh nyata terhadap produksi wortel. Penelitian juga menemukan, penggunaan bibit, pupuk kandang, pupuk Ammophos, pupuk NPK, pupuk KCL, pestisida Antracol, pestisida Gramoxone, dan tenaga kerja belum efisien. Pendapatan bersih petani wortel mencapai Rp 27.763.882,28/hektar/musim tanam.
\end{abstract}

Kata kunci: faktor produksi, produktivitas, efisiensi, pendapatan

Abstract

Simpang Empat District is a producer of carrots in Karo Regency. Comparing the land area and productivity of carrots in this area with Berastagi District, the area of carrots in this area is 674 ha, while in Berastagi it is 186 ha, while in terms of productivity Berastagi is much better (22.46 tonnes/ha versus 28.44 tonnes/ha ).This research is located in Surbakti Village, Simpang Empat District. Based on the presurvey, the production factors used in this village are seeds, manure, Ammophos fertilizer, NPK fertilizer, KCL fertilizer, Antracol pesticide, Gramoxone pesticide, and labor. This study aims to analyze the effect of the eight factors on production, level of efficiency, and income of carrot farming in the research area. The findings of this study indicate, simultaneously ( $\mathrm{F}$ test) the use of seed production factors, manure, Ammophos fertilizer, NPK fertilizer, KCL fertilizer, Antracol pesticide, Gramoxone pesticide, and labor have a significant effect on the production of carrot farming in the study area. Partially (t-test) seeds, manure, Ammophos fertilizer, NPK fertilizer, KCL fertilizer, Antracol pesticide, Gramoxone pesticide, and labor have a significant effect on carrot production, while KCL fertilizer has no significant effect on carrot production. The study also found that the use of seeds, manure, Ammophos fertilizer, NPK fertilizer, KCL fertilizer, Antracol pesticide, Gramoxone pesticide, and labor was not efficient. The net income of carrot farmers reached IDR 27,763,882.28/hectare/planting season.

Keywords: production factors, productivity, efficiency, income

\section{PENDAHULUAN}

Sumatera Utara menyumbang produksi wortel sebesar 50.900 ton pada lahan seluas 2.591 ha dengan produktivitas sebesar 19,64 ton/ha. Ini lebih baik dari produktivitas nasional yang 17,53 ton/ha (BPS 2018).

Kabupaten Karo merupakan salah satu sentra produksi wortel di Provinsi Sumatera Utara. Dari segi produktivitas, meski memperlihatkan kecenderungan menurun dari 2015-2017, namun luas lahan justru menunjukkan peningkatan kecuali di tahun 2016 (Tabel 1).

Tabel 1. Luas Panen, Produksi, dan Produktivitas

Wortel di Kabupaten Karo Tahun 2013-2017
\begin{tabular}{|c|c|c|c|}
\hline Tahun & $\begin{array}{c}\text { Luas } \\
\text { Panen } \\
\text { (Ha) }\end{array}$ & $\begin{array}{c}\text { Produksi } \\
\text { (Ton) }\end{array}$ & $\begin{array}{c}\text { Produktivitas } \\
\text { (Ton/Ha) }\end{array}$ \\
\hline 2013 & 1.586 & 33.613 & 21,19 \\
2014 & 1.738 & 36.257 & 20,86 \\
2015 & 2.062 & 46.093 & 22,35 \\
2016 & 2.020 & 43.089 & 21,33 \\
2017 & 2.353 & 48.092 & 20,43 \\
\hline Jumlah & $\mathbf{9 . 7 5 9}$ & $\mathbf{2 0 7 . 1 4 4}$ & $\mathbf{1 0 6 , 1 6}$ \\
\hline Rataan & $\mathbf{1 . 9 5 1 , 8}$ & $\mathbf{4 1 . 4 2 8 , 8}$ & $\mathbf{2 1 , 2 3}$ \\
\hline
\end{tabular}

Salah satu kecamatan penghasil wortel di 
Kabupaten Karo adalah Kecamatan Simpang Empat. Dari segi luas panen, daerah ini menduduki peringkat kedua, namun dari sisi produktivitas berada di posisi kelima dari delapan kecamatan (Tabel 2).

Tabel 2. Luas Panen, Produksi dan Produktivitas Wortel menurut Kecamatan di Kabupaten Karo

\begin{tabular}{|c|c|c|c|c|}
\hline \multicolumn{5}{|c|}{2017} \\
\hline No & Kecamatan & $\begin{array}{l}\text { Luas Panen } \\
\text { (Ha) }\end{array}$ & $\begin{array}{l}\text { Produksi } \\
\text { (Ton) }\end{array}$ & $\begin{array}{l}\text { Produktivitas } \\
\text { (Ton/Ha) }\end{array}$ \\
\hline 1 & Simpang Empat & 674 & 15.138 & 22,46 \\
\hline 2 & Naman Teran & 18 & 453 & 25,17 \\
\hline 3 & Merdeka & 638 & 14.386 & 22,55 \\
\hline 4 & Kabanjahe & 182 & 3.640 & 20,00 \\
\hline 5 & Berastagi & 186 & 5.290 & 28,44 \\
\hline 6 & Tigapanah & 780 & 16.531 & 21,19 \\
\hline 7 & Merek & 100 & 1.485 & 14,85 \\
\hline 8 & Barusjahe & 151 & 3.728 & 24,69 \\
\hline & Jumlah & 2.729 & 60.651 & 22,22 \\
\hline
\end{tabular}

Sumber: Badan Pusat Statistika 2018

Ada yang menarik dari sisi luas lahan dan produktivitas wortel dari Kecamatan Simpang Empat dibandingkan dengan Kecamatan Berastagi. Luas lahan wortel di Kecamatan Simpang Empat, bila dihitung 3,62 kali lebih luas, sementara dari segi produktivitas, Kecamatan Berastagi jauh lebih baik.

Salah satu desa penghasil wortel di Kecamatan Simpang Empat adalah Desa Surbakti. Berdasarkan prasurvei, faktor-faktor produksi yang digunakan di desa ini adalah bibit, pupuk kandang, pupuk Ammophos, pupuk NPK, pupuk KCL, pestisida Antracol, pestisida Gramoxone, dan tenaga kerja. Dengan demikian, penelitian ini bertujuan menganalisis pengaruh bibit, pupuk kandang, pupuk Ammophos, pupuk NPK, pupuk KCL, pestisida Antracol, pestisida Gramoxone, dan tenaga kerja terhadap produksi, tingkat efisiensi, dan pendapatan usahatani wortel di Desa Surbakti, Kecamatan Simpang Empat, Kabupaten Karo. Sejumlah penelitian dengan topik yang sama dilakukan oleh Devi et al. (2014), Moekani (2014), Rosihan (2016), Agustin (2017), Eko et al. (2017), Richard (2017), dan Rosadi (2018).

Penelitian ini memiliki dua hipotesis:

1. Faktor produksi bibit, pupuk kandang, pupuk Ammophos, pupuk NPK, pupuk KCL, pestisida Antracol, pestisida Gramoxone, dan tenaga kerja berpengaruh nyata terhadap produksi wortel di Desa Surbakti.

2. Penggunaan faktor produksi bibit, pupuk kandang, pupuk Ammophos, pupuk NPK, pupuk KCL, pestisida Antracol, pestisida Gramoxone, dan tenaga kerja di Desa Surbakti sudah efisien.

\section{METODE PENELITIAN}

Daerah penelitian ditentukan secara purposif di Desa Surbakti, Kecamatan Simpang Empat, Kabupaten Karo. Alasan pemilihan daerah penelitian adalah karena desa tersebut merupakan sentra produksi tanaman wortel.

Populasi penelitian ini adalah 300 kepala keluarga (KK) petani wortel di Desa Surbakti. Dari populasi tersebut diambil $30 \mathrm{KK}$ sampel secara acak sederhana (simple random sampling).

Data yang digunakan dalam penelitian ini adalah data primer dan data sekunder. Data primer diperoleh dengan melakukan wawancara dan pengamatan langsung ke petani dengan menggunakan kuesioner yang telah disiapkan sebelumnya. Data sekunder diperoleh dari Badan Pusat Statistika dan Kantor Kepala Desa Surbakti.

Untuk menganalisis pengaruh bibit, pupuk kandang, pupuk Ammophos, pupuk NPK, pupuk KCL, pestisida Antracol, pestisida Gramoxone, dan tenaga kerja terhadap produksi wortel digunakan fungsi produksi Cobb-Douglas dengan rumus sebagai berikut:

$$
\mathrm{Y}=\mathrm{b}_{\mathrm{o}} \mathrm{X}_{1}{ }^{\mathrm{b} 1} \mathrm{X}_{2}{ }^{\mathrm{b} 2} \mathrm{X}_{3}{ }^{\mathrm{b} 3} \mathrm{X}_{4}{ }^{\mathrm{b} 4} \mathrm{X}_{5}{ }^{\mathrm{b} 5} \mathrm{X}_{6}{ }^{\mathrm{b} 6} \mathrm{X}_{7}{ }^{\mathrm{b} 7} \mathrm{X}_{8}{ }^{\mathrm{b} 8} \mathrm{e}^{\mu}
$$

di mana:

$$
\begin{aligned}
& \mathrm{Y}=\text { Produksi }(\text { Ton }) \\
& \mathrm{X} 1=\text { Bibit } \\
& \mathrm{X} 2=\text { Pupuk kandang }(\mathrm{kg}) \\
& \mathrm{X} 3=\text { Pupuk Ammophos } \\
& \mathrm{X} 4=\text { Pupuk NPK }(\mathrm{kg}) \\
& \mathrm{X} 5=\text { Pupuk KCL }(\mathrm{kg}) \\
& \text { X6 = Pestisida Antracol (liter) } \\
& \mathrm{X} 7=\text { Pestisida Gramoxone (liter) } \\
& \mathrm{X} 8=\text { Tenaga Kerja (HKP) } \\
& \mathrm{b}_{0} \quad=\text { Intercept } \text { atau konstanta }
\end{aligned}
$$

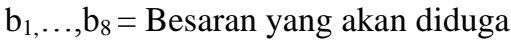

$$
\begin{aligned}
& \text { e } \quad=\text { Bilangan natural }(\mathrm{e}=2,718) \\
& \mu \quad=\text { Galat }
\end{aligned}
$$

Persamaan Cobb-Douglas di atas kemudian diubah ke dalam bentuk linier berganda sebagai berikut:

$\ln \mathrm{Y}=\ln \mathrm{b}_{0}+\mathrm{b}_{1} \ln \mathrm{X}_{1}+\mathrm{b}_{2} \ln \mathrm{X}_{2}+\mathrm{b}_{3} \ln \mathrm{X}_{3}+$ $\mathrm{b}_{4} \ln \mathrm{X}_{4}+\mathrm{b}_{5} \ln \mathrm{X}_{5}+\mathrm{b}_{6} \ln \mathrm{X}_{6}+\mathrm{b}_{7} \ln \mathrm{X}_{7}+\mathrm{b}_{8} \ln \mathrm{X}_{8}+\mu$ Persamaan ini kemudian diuji dengan menggunakan uji F: 
F Hitung $=\frac{R^{2} / k}{1-R^{2} /(n-k-1)}$

di mana:

$\mathrm{R}^{2}=$ Koefisien Determinasi

$\mathrm{n}=$ Jumlah sampel

$\mathrm{k}=$ Jumlah variabel independen

pada taraf $\alpha=5 \%$

Kriteria uji untuk Hipotesis 1 adalah:

- F-hitung < F-tabel : Hipotesis $\mathrm{H}_{0}$ diterima

- F-hitung $\geq$ F-tabel : Hipotesis $\mathrm{H}_{1}$ diterima ( $\mathrm{H}_{0}$ ditolak) (Supranto, 1994)

Uji-t dilakukan dengan rumus:

$t-$ hitung $: \frac{\mathbf{b i}-\mathbf{b}}{\text { Sbi }}$

di mana:

$\mathrm{b}_{1} \quad=$ koefisien variabel ke-1

$\mathrm{b} \quad=$ nilai hipotesis 0

$\mathrm{S}(\mathrm{bi})=$ simpangan baku dari variabel $\mathrm{ke}-\mathrm{i}$ pada taraf $\alpha=5 \%$

Kriteria uji :

- $\quad \mathrm{t}$-hitung $<\mathrm{t}$-tabel : Hipotesis $\mathrm{H}_{0}$ diterima

- $\quad \mathrm{t}$-hitung $\geq \mathrm{t}$-tabel : Hipotesis $\mathrm{H}_{1}$ diterima $\left(\mathrm{H}_{0}\right.$ ditolak) (Ghozali 2011).

Untuk Hipotesis 2 dianalisis berdasarkan konsep efisiensi harga, yaitu perbandingan nilai produk marginal (NPM) dengan harga input (Px). Secara matematis dapat dituliskan sebagai berikut:

$\mathrm{NPMx}=\mathrm{Px}$; atau

$\frac{\mathrm{NPMx}}{\mathrm{Px}}=1$

Pengujian Hipotesis 2 dilakukan dengan ketentuan:

$\mathrm{H}_{0}$ : ki $=1$, berarti bahwa secara ekonomis penggunaan input sudah efisien.
$\mathrm{H}_{1}$ : ki $\neq 1$, berarti bahwa secara ekonomis penggunaan input belum efisien.

di mana:

$$
\begin{aligned}
& \mathrm{K}_{\mathrm{i}}=\mathrm{b}_{\mathrm{i}} \frac{\overline{\mathrm{Y}} \cdot \overline{\mathrm{P}}_{\mathrm{y}}}{\overline{\mathrm{X}}_{\mathrm{i}} \cdot \overline{\mathrm{Px}}_{\mathrm{i}}} \\
& \sigma \mathrm{K}_{\mathrm{i}}=\sigma \mathrm{b}_{\mathrm{i}} \cdot \frac{\overline{\mathrm{Y}} \cdot \overline{\mathrm{P}}_{\mathrm{y}}}{\overline{\mathrm{P}}_{\mathrm{i}} \cdot \overline{\mathrm{X}}_{\mathrm{i}}} \\
& \mathrm{t}_{\text {hitung }}=\frac{\mathrm{K}_{\mathrm{i}}-1}{\sigma \mathrm{K}_{\mathrm{i}}}
\end{aligned}
$$

Apabila $\mathrm{t}$ hitung $\geq \mathrm{t}$ tabel, maka $\mathrm{H}_{0}$ ditolak, artinya bahwa penggunaan faktor produksi ke-i sudah efisien (Saragi 1992).

\section{Pendapatan}

Pendapatan usahatani dapat dihitung dengan rumus:

$\mathrm{Pd}=\mathrm{TR}-\mathrm{TC}$

di mana:

$\mathrm{Pd}=$ Pendapatan usahatani $(\mathrm{Rp})$

$\mathrm{TR}=$ Total Revenue $($ Total penerimaan $)$

$\mathrm{TC}=$ Total Cost (Total biaya) (Soekartawi 2002)

\section{HASIL DAN PEMBAHASAN}

Hasil analisis fungsi produksi Cobb-Douglas usahatani wortel di daerah penelitian dapat dilihat pada Tabel 3.

Berdasarkan hasil analisis fungsi produksi Cobb-Douglass diperoleh persamaan regresi sebagai berikut:

$\ln \mathrm{Y}=\ln 2.37+0.82 \ln \mathrm{X}_{1}+0.03 \ln \mathrm{X}_{2}-0.16 \ln \mathrm{X}_{3}+$ $0.35 \ln X_{4}-0.14 \ln X_{5}-0.19 \ln X 6+0.08 \ln X 7+0.67$ $\ln \mathrm{X} 8$

\begin{tabular}{|c|c|c|c|c|c|c|c|}
\hline \multirow[b]{2}{*}{ Model } & \multicolumn{2}{|c|}{$\begin{array}{l}\text { Unstandardized } \\
\text { Coefficients }\end{array}$} & \multirow{2}{*}{$\begin{array}{c}\text { Standardized } \\
\text { Coefficients } \\
\text { Beta }\end{array}$} & \multirow[b]{2}{*}{$\mathrm{T}$} & \multirow[b]{2}{*}{ Sig. } & \multicolumn{2}{|c|}{ Collinearity Statistics } \\
\hline & B & $\begin{array}{l}\text { Std. } \\
\text { Error }\end{array}$ & & & & Tolerance & VIF \\
\hline (Constant) & 2.370 & .605 & & 3.918 & .001 & & \\
\hline Bibit & .822 & .153 & .732 & $5.378^{*}$ & .000 & .038 & 26.398 \\
\hline Pupuk_Kandang & .028 & .146 & .026 & $.191^{\mathrm{tn}}$ & .850 & .038 & 26.177 \\
\hline Pupuk_Ammophos & -.157 & .150 & -.117 & $-1.050^{\mathrm{tn}}$ & .306 & .056 & 17.785 \\
\hline Pupuk_NPK & .352 & .144 & .306 & $2.444 *$ & .023 & .045 & 22.345 \\
\hline Pupuk_KCL & -.144 & .144 & -.088 & $-1.000^{\mathrm{tn}}$ & .329 & .090 & 11.098 \\
\hline Pestisida_Antracol & -.185 & .166 & -.132 & $-1.113^{\mathrm{tn}}$ & .278 & .050 & 20.005 \\
\hline Pestisida_Gramoxone & .075 & .095 & .042 & $.792^{\mathrm{tn}}$ & .437 & .255 & 3.925 \\
\hline Tenaga_Kerja & .668 & .443 & .233 & $1.509^{\mathrm{tn}}$ & .146 & .029 & 34.012 \\
\hline
\end{tabular}

Tabel 3. Hasil Perhitungan Koefisien Regresi terhadap Produksi Usahatani Wortel, thitung pada Tingkat Kepercayaan $95 \%$

Sumber: Data diolah

Keterangan: * = signifikan (nyata) pada tingkat kepercayaan $95 \%$

tn $=$ tidak signifikan (tidak nyata)

$$
\mathrm{R}^{2}=0.985
$$

F-hit $=175.406$

t-tabel $(0.05)=1.717$ 
Tabel 3 menunjukkan nilai $\mathrm{F}_{\text {hitung }}>\mathrm{F}_{\text {tabel }}$ pada tingkat $\alpha 0.05$. Hal ini memberikan indikasi bahwa secara serempak variabel bibit, pupuk kandang, pupuk Ammophos, pupuk NPK, pupuk KCL, pestisida Antracol, pestisida Gramoxone, dan tenaga kerja berpengaruh nyata terhadap produksi wortel.

Berdasarkan hasil pengujian diperoleh nilai koefisien determinasi $\left(\mathrm{R}^{2}\right)$ sebesar 0,985. Hal ini memberikan indikasi bahwa $98,5 \%$ variasi variabel dependen dapat dijelaskan oleh variasi variabel independen yang terdapat di dalam model.
Dari hasil analisis I tersebut diduga ada gejala multikolinearitas. Hal ini dapat berarti secara parsial hanya beberapa variabel independen yang berpengaruh nyata terhadap produksi. Dari matrix correlation atau nilai VIF $>10$ dapat dilihat terjadi tarik menarik yang sangat kuat di antara variabel independen.

Untuk menghindari multikolinearitas, dilakukan analisis II dengan mengurangkan atau mengeluarkan dua variabel independen, yakni pupuk Ammophos (X3), dan pestisida Gramoxone (X7). Hasil pengujian tersebut dapat dilihat pada Tabel 4.

Tabel 4. Hasil Perhitungan Koefisien Regresi terhadap Produksi Usahatani Wortel, thitung pada Tingkat Kepercayaan $95 \%$ dengan Mengurangi Variabel Pupuk Ammophos dan Pestisida Gramoxone

\begin{tabular}{|l|c|c|c|c|c|c|c|}
\hline & \multicolumn{2}{|c|}{$\begin{array}{c}\text { Unstandardized } \\
\text { Coefficients }\end{array}$} & $\begin{array}{c}\text { Standardized } \\
\text { Coefficients }\end{array}$ & & \multicolumn{3}{|c|}{$\begin{array}{c}\text { Collinearity } \\
\text { Statistics }\end{array}$} \\
\cline { 2 - 5 } Model & $\mathrm{B}$ & Std. Error & Beta & $\mathrm{t}$ & Sig. & Tolerance & VIF \\
\cline { 1 - 7 } (Constant) & .746 & .594 & & 1.257 & .221 & & \\
Bibit & .345 & .138 & .333 & $2.508^{*}$ & .020 & .058 & 17.162 \\
Tenaga_Kerja & 1.164 & .420 & .439 & $2.772^{*}$ & .011 & .041 & 24.514 \\
Pupuk_Kandang & -.067 & .073 & -.084 & $-.913^{\text {tn }}$ & .371 & .120 & 8.346 \\
Pupuk_NPK & .413 & .148 & .389 & $2.784^{*}$ & .011 & .052 & 19.084 \\
Pupuk_KCL & -.256 & .160 & -.186 & $-1.599^{\text {tn }}$ & .123 & .075 & 13.254 \\
Pestisida_Antracol & .207 & .091 & .124 & $2.290^{*}$ & .032 & .350 & 2.856 \\
\hline
\end{tabular}

Sumber: Data diolah

Keterangan : * = signifikan (nyata) pada tingkat kepercayaan $95 \%$

$$
\begin{aligned}
& \text { tn }=\text { tidak signifikan (tidak nyata) } \\
& \mathrm{R}^{2}=0.976 ; \text { F-hit }=158.861 ; \text { dan } \mathrm{t} \text {-tabel }(0.05)=1.710
\end{aligned}
$$

Berdasarkan hasil analisis II fungsi produksi Cobb-Douglass diperoleh persamaan regresi sebagai berikut:

$\ln \mathrm{Y}=\ln 0.746+0.345 \ln \mathrm{X}_{1}+1.164 \ln \mathrm{X}_{2}-0.067$ $\ln \mathrm{X}_{3}+0.413 \ln \mathrm{X}_{4}-0.256 \ln \mathrm{X}_{5}+0.207 \ln \mathrm{X} 6$

Dari Tabel 4 diduga masih terjadi gejala multikolinearitas. Ini dapat dilihat dari matrix correlation di mana terjadi tarik menarik yang kuat di antara variabel independen atau nilai Vif $>10$.

Selanjutnya untuk menghindari adanya gejala multikolinearitas maka dilakukan analisis III, yaitu dengan mengurangkan atau mengeluarkan satu variabel independen lain, yakni bibit (X1). Hasil analisis III dapat dilihat pada Tabel 5.

Tabel 5. Hasil Perhitungan Koefisien Regresi terhadap Produksi Usahatani Wortel, thitung pada Tingkat Kepercayaan $=95 \%$ dengan Mengurangi Variabel Bibit

\begin{tabular}{|l|c|c|c|c|c|c|c|}
\hline & \multicolumn{2}{|c|}{$\begin{array}{c}\text { Unstandardized } \\
\text { Coefficients }\end{array}$} & $\begin{array}{c}\text { Standardized } \\
\text { Coefficients }\end{array}$ & & \multicolumn{3}{|c|}{$\begin{array}{c}\text { Collinearity } \\
\text { Statistics }\end{array}$} \\
\cline { 2 - 5 } \cline { 6 - 8 } Model & $\mathrm{B}$ & Std. Error & Beta & $\mathrm{t}$ & Sig. & Tolerance & VIF \\
\hline (Constant) & .935 & .285 & & 3.283 & .003 & & \\
Tenaga_Kerja & .679 & .286 & .304 & $2.370^{*}$ & .026 & .055 & 18.045 \\
Pupuk_Kandang & .195 & .074 & .279 & $2.629^{*}$ & .015 & .081 & 12.356 \\
Pupuk_NPK & .262 & .112 & .292 & $2.343^{*}$ & .028 & .059 & 17.081 \\
Pupuk_KCL & .100 & .101 & .050 & $.991^{\text {tn }}$ & .331 & .357 & 2.804 \\
Pestisida_Antracol & .183 & .090 & .130 & $2.028^{*}$ & .054 & .223 & 4.486 \\
\hline
\end{tabular}

Sumber: Data diolah

Keterangan $: *=$ signifikan (nyata) pada tingkat kepercayaan $95 \%$

tn $=$ tidak signifikan (tidak nyata)
$\mathrm{R}^{2}=0.878 ;$ F-hit $=214.707 ;$ dan $\mathrm{t}$-tabel $(0.05)=$ 1.708 
Berdasarkan hasil analisis fungsi produksi Cobb-Douglass diperoleh persamaan regresi sebagai berikut :

$$
\begin{aligned}
& \ln \mathrm{Y}=\ln 0.93+0.679 \ln \mathrm{X}_{1}+0.195 \ln \mathrm{X}_{2}+0.262 \\
& \ln \mathrm{X}_{3}+0.100 \ln \mathrm{X}_{4}+0.183 \ln \mathrm{X}_{5}
\end{aligned}
$$

Untuk pembahasan selanjutnya digunakan analisis III yaitu pada Tabel 5 di mana terdapat 4 dari 5 variabel yang berpengaruh nyata. Untuk mengetahui lebih jelas pengaruh dari masing-masing variabel atau faktor produksi terhadap produksi usahatani wortel diinterpretasikan dengan uji $\mathrm{F}$ dan uji-t.

Uji F diperlukan untuk mengetahui pengaruh variabel independen $\left(\mathrm{X}_{\mathrm{i}}\right)$ secara serempak atau bersama-sama terhadap variabel dependen (terikat) yaitu produksi wortel (Y) pada tingkat $\alpha 0,05$ dengan F tabel sebesar 2,60.

Hasil perhitungan memperlihatkan nilai $F$ hitung yang lebih besar dari nilai $\mathrm{F}$ tabel pada $\alpha 0,05$. Hal ini menunjukkan bahwa secara serempak variabel independen yaitu jumlah tenaga kerja $\left(\mathrm{X}_{1}\right)$, jumlah pupuk kandang $\left(\mathrm{X}_{2}\right)$, jumlah pupuk NPK $\left(\mathrm{X}_{3}\right)$, jumlah pupuk KCL $\left(\mathrm{X}_{4}\right)$, dan pestisida antracol $\left(\mathrm{X}_{5}\right)$ berpengaruh nyata terhadap variabel dependen yaitu produksi wortel (Y). Ini sesuai kriteria uji yang menyatakan apabila $\mathrm{F}$ hitung $>\mathrm{F}$ tabel maka $\mathrm{H}_{1}$ diterima.

Dari hasil perhitungan diperolah nilai koefisien determinasi $\left(\mathrm{R}^{2}\right)$ sebesar 0,878. Ini menandakan bahwa sebesar $87,8 \%$ variasi variabel dependen (produksi) dapat dijelaskan oleh faktor produksi atau variabel independen (tenaga kerja, pupuk kandang, pupuk NPK, pupuk KCL, dan pestisida Antracol), sedangkan sisanya sebesar $12,2 \%$ dijelaskan oleh variabel lain yang tidak diteliti.

Uji-t diperlukan untuk mengetahui pengaruh variabel independen $\left(\mathrm{X}_{\mathrm{i}}\right)$ secara parsial atau masingmasing variabel independen terhadap variabel dependen yaitu produksi wortel (Y) pada tingkat $\alpha$ 0,05 dengan t tabel sebesar 1,708.

Dari persamaan fungsi produksi Cobb-Douglass di atas dapat dilihat bahwa elastisitas produksi untuk penggunaan tenaga kerja $\left(\mathrm{X}_{2}\right)$ sebesar 0,679 dan bertanda positif. Hal ini menunjukkan bahwa secara relatif dengan penambahan $1 \%$ jumlah tenaga kerja dapat meningkatkan produksi usahatani wortel sebesar $0,679 \%$ dengan asumsi faktor lain tetap (ceteris paribus).

Nilai $t_{\text {hitung }}(2,370)>t_{\text {tabel }}(1,708)$ pada tingkat kepercayaan $95 \%$, sehingga $\mathrm{H}_{1}$ diterima. Artinya, secara parsial variabel tenaga kerja berpengaruh nyata pada produksi wortel.

Dari persamaan fungsi produksi Cobb-Douglass di atas dapat dilihat bahwa elastisitas produksi untuk pupuk kandang $\left(\mathrm{X}_{3}\right)$ sebesar 0,195 dan bertanda positif. Ini berarti bahwa secara relatif dengan penambahan $1 \%$ pupuk kandang akan meningkatkan produksi sebesar $0,195 \%$ dengan asumsi faktor lain tetap (ceteris paribus).
Nilai $t_{\text {hitung }}(2,629)>t_{\text {tabel }}(1,708)$ pada tingkat kepercayan 95\%, sehingga $\mathrm{H}_{1}$ diterima. Artinya, secara parsial pemberian pupuk kandang berpengaruh nyata terhadap produksi wortel.

Dari persamaan fungsi produksi Cobb-Douglass di atas dapat dilihat bahwa elastisitas produksi untuk penggunaan pupuk $\left(\mathrm{X}_{4}\right)$ sebesar 0,262 dan bertanda positif. Hal ini menunjukkan bahwa secara relatif dengan penambahan $1 \%$ pupuk dapat meningkatkan produksi wortel sebesar 0,262\% dengan asumsi faktor lain tetap (ceteris paribus).

Nilai $t_{\text {hitung }}(2,343)>t_{\text {tabel }}(1,708)$ pada tingkat kepercayaan 95\%, sehingga $\mathrm{H}_{1}$ diterima. Artinya, secara parsial variabel pupuk berpengaruh nyata terhadap produksi wortel.

Dari persamaan fungsi produksi Cobb-Douglass di atas dapat dilihat bahwa elastisitas produksi untuk pupuk KCL $\left(\mathrm{X}_{4}\right)$ sebesar 0,100 dan bertanda positif. Hal ini menunjukkan bahwa secara relatif dengan penambahan $1 \%$ pupuk KCL dapat meningkatkan produksi sebesar $0,100 \%$ dengan asumsi faktor lain tetap (ceteris paribus).

Nilai $t_{\text {hitung }}(0,991)<t_{\text {tabel }}(1,708)$ pada tingkat kepercayaan $95 \%$, sehingga $\mathrm{H}_{0}$ diterima. Artinya, secara parsial variabel pupuk KCLtidak berpengaruh nyata terhadap produksi wortel.

Dari persamaan fungsi produksi Cobb-Douglass di atas dapat dilihat bahwa elastisitas produksi untuk penggunaan petisida Antracol $\left(\mathrm{X}_{5}\right)$ sebesar 0,183 bertanda positif. Hal ini menunjukkan bahwa secara relatif dengan penambahan $1 \%$ jumlah pestisida Antracol dapat meningkatkan produksi $0,183 \%$ dengan asumsi faktor lain tetap.

Nilai $t_{\text {hitung }}(2,028)>t_{\text {tabel }}(1,708)$ pada tingkat kepercayaan $95 \%$, sehingga $\mathrm{H}_{1}$ diterima. Artinya, secara parsial penggunaan petisida Antracol berpengaruh nyata terhadap produksi wortel.

Tabel 6 menyajikan pengujian efisiensi penggunaan faktor-faktor produksi melalui fungsi produksi.

Tabel 6. Pengujian Efisiensi Penggunaan Faktor-

Faktor Produksi Usahatani Wortel m,elalui Pendekatan Fungsi Produksi

\begin{tabular}{|l|l|c|c|}
\hline No & Variabel & Nilai $_{\mathrm{i}}$ & t-hitung \\
\hline 1 & Tenaga Kerja & 2,87 & 2,37 \\
2 & Pupuk & 5,85 & 2,18 \\
& Kandang & & \\
3 & Pupuk NPK & 7,21 & 2,01 \\
4 & Pupuk KCL & 6,85 & 0,84 \\
5 & Pestisida & 31,93 & 2,03 \\
& Antracol & & \\
\hline
\end{tabular}

Sumber : Data diolah

Nilai Ki merupakan indeks efisiensi dari alokasi setiap faktor produksi. Tingkat efisiensi faktorfaktor produksi pada usahatani wortel dapat diketahui dengan melakukan pengujian efisiensi alokatif. Uji efisiensi alokatif dapat dilakukan dengan mengetahui nilai dari indeks efisiensi atau Ki. Indeks efisiensi 
alokatif (Ki) merupakan perbandingan nilai produk marginal (NPM) dan harga faktor produksi (Px).

Rasio antara NPM dari faktor produksi tenaga kerja dengan harga per kg-nya adalah lebih besar dari satu (2,87). Hal ini menunjukkan bahwa penggunaan dari faktor produksi tenaga kerja ratarata sebesar 110,11 $\mathrm{HKP} / \mathrm{ha}$ pada saat penelitian dilakukan relatif belum efisien. Dengan demikian, usaha untuk meningkatkan keuntungan petani di daerah penelitian masih memungkinkan, yaitu dengan penambahan penggunaan tenaga kerja sampai tercapai rasio NPMx sama dengan satu. Hal ini dapat dilihat dari nilai t-hitung $(2,37)>$ t-tabel $(1,708)$ pada $\alpha=5 \%$, yang menunjukkan bahwa secara relatif dengan penambahan tenaga kerja masih memungkinkan bertambahnya produksi usahatani wortel. Menurut Dinas Pertanian (2015) penggunaan tenaga kerja dalam 1 hektar adalah sebanyak 160 $\mathrm{HKP} / \mathrm{ha}$.

Rasio antara NPM dari faktor produksi pupuk kandang dengan harga per kg-nya adalah lebih besar dari satu $(5,85)$. Hal ini menunjukkan bahwa penggunaan dari faktor produksi pupuk kandang sebanyak 4,215.63 kg/ha pada saat penelitian dilakukan relatif belum efisien. Dengan demikian usaha untuk meningkatkan keuntungan petani di daerah penelitian masih memungkinkan yaitu dengan penambahan pupuk kandang sampai tercapai rasio NPMx $=1$. Hal ini dapat dilihat dari nilai t-hitung $(2,18)>$ t-tabel $(1,708)$ pada $\alpha=5 \%$. Ini menunjukkan bahwa secara relatif dengan penambahan pupuk kandang masih memungkinkan bertambahnya produksi usahatani wortel. Menurut Kementerian Pertanian (2014) dosis pupuk kandang pada wortel adalah $10.000 \mathrm{~kg} / \mathrm{ha}$.

Rasio NPM dari faktor produksi pupuk NPK dan harga per kg-nya adalah lebih besar dari satu $(7,21)$. Hal ini menunjukkan bahwa penggunaan faktor produksi pupuk NPK sebanyak 146,21 kg/ha pada saat penelitian dilakukan relatif belum efisien. Dengan demikian usaha untuk meningkatkan keuntungan petani di daerah penelitian masih memungkinkan yaitu dengan penambahan pupuk NPK sampai tercapai rasio NPMx $=1$. Hal ini dapat dilihat dari nilai t-hitung $(2,01)>$ t-tabel $(1,708)$ pada $\alpha=5 \%$. Ini menunjukkan bahwa secara relatif dengan penambahan pupuk NPK masih memungkinkan bertambahnya produksi usahatani wortel. Menurut Kementerian Pertanian (2014) penggunaan pupuk KCL adalah $1.300 \mathrm{~kg} / \mathrm{ha}$.

Rasio antara NPM dari faktor produksi pupuk KCL dengan harga per kg-nya adalah lebih besar dari satu $(6,85)$. Hal ini menunjukkan bahwa penggunaan dari faktor produksi pupuk KCL sebanyak 80,74 $\mathrm{kg} / \mathrm{ha}$ pada saat penelitian dilakukan relatif belum efisien. Dengan demikian usaha untuk meningkatkan keuntungan petani di daerah penelitian masih memungkinkan yaitu dengan penambahan pupuk KCL sampai tercapai rasio NPMx $=1$. Hal ini dapat dilihat dari nilai t-hitung $(0,84)<\mathrm{t}$-tabel $(1,708)$ pada $\alpha=5 \%$. Walaupun hasil uji pupuk KCL tidak signifikan tetapi dilihat dari nilai tren koefisien dari pupuk KCL yang bernilai positif, penambahan penggunaan pupuk KCL masih dapat meningkatkan produksi wortel. Menurut Kementerian Pertanian (2014) penggunaan pupuk KCL adalah 150 kg/ha.

Rasio antara NPM dari faktor produksi pestisida Antracol dengan harga per kg-nya adalah lebih besar dari satu (31,93). Hal ini menunjukkan bahwa penggunaan faktor produksi rata-rata pestisida Antracol sebanyak 2,372 g/ha pada saat penelitian dilakukan relatif belum efisien. Dengan demikian usaha untuk meningkatkan keuntungan petani di daerah penelitian masih memungkinkan, yaitu dengan penambahan pestisida Antracol sampai tercapai rasio NPMx $=1$. Hal ini dapat dilihat dari nilai t-hitung $(2,03)>$ t-tabel $(1,708)$ pada $\alpha=5 \%$. Ini memperlihatkan bahwa secara relatif dengan penambahan pestisida Antracol masih memungkinkan bertambahnya produksi usahatani wortel. Menurut Kementerian Pertanian (2015) kebutuhan pestisida dalam luasan 1 hektar adalah 6 liter/hektar.

Bisa disimpulkan, secara serempak penggunaan faktor produksi bibit, pupuk kandang, pupuk Ammophos, pupuk NPK, pupuk KCL, pestisida Antracol, pestisida Gramoxone, dan tenaga kerja berpengaruh nyata terhadap produksi usahatani wortel di Desa Surbakti. Secara parsial (uji-t) bibit, pupuk kandang, pupuk Ammophos, pupuk NPK, pestisida Antracol, pestisida Gramoxone, dan tenaga kerja berpengaruh nyata terjadap produksi wortel, sedangkan pupuk KCL tidak berpengaruh nyata terhadap produksi wortel di daerah penelitian.

Penelitian ini berbeda dengan penelitian Agustin (2017). Penelitian Agustin memasukkan pengaruh luas lahan yang bersama benih dan pupuk organik berpengaruh nyata pada produksi wortel.

Besarnya penerimaan dan pendapatan bersih rata-rata petani wortel di Desa Surbakti dapat dilihat pada Tabel 7.

Tabel 7. Penerimaan dan Pendapatan Bersih Usahatani Wortel Selama Satu Musim Tanam di Desa Surbakti Tahun 2019 (Rp/Musim Tanam)

\begin{tabular}{|l|l|l|l|}
\hline No & Uraian & \multicolumn{2}{|c|}{ Jumlah (Rp) } \\
\cline { 3 - 4 } & & Per Petani & Per Hektar \\
\hline 1 & Penerimaan & $32.113 .333,33$ & $44.294 .251,87$ \\
2 & Biaya Produksi & $11.984 .518,68$ & $16.530 .370,60$ \\
3 & Pendapatan Bersih & $20.128 .814,65$ & $27.763 .882,28$ \\
\hline
\end{tabular}


Sumber : Data diolah

Tabel 7 menunjukkan bahwa besar penerimaan usahatani wortel ialah Rp44.294.251,87/hektar/musim tanam. Pada saat penelitian, harga wortel di tingkat petani di Desa Surbakti adalah Rp 2.000,00/kg. Mengingat biaya produksi pada penelitian ini per hektar adalah Rp16,53 juta, maka diperoleh pendapatan bersih usahatani wortel sebesar Rp27,76 juta/hektar/musim tanam. Keuntungan yang diperoleh petani wortel di Desa Surbakti ini lebih tinggi dari petani di Desa Ngabab yang Rp21,20 juta (Rosadi 2018) dan Rp11,11 juta (Agustin 2017), di Desa Surbakti yang Rp15.09 juta (Richard 2017), di Desa Bengko yang Rp9,35 juta (Eko et al. 2017), di Kecamatan Bumiaji yang Rp32,76 juta (Rosihan 2016), dan di Desa Suban Ayam yang Rp4,81 juta (Devi et al. 2014).

\section{KESIMPULAN}

Temuan penelitian ini menunjukkan:

1. Secara serempak (uji F) penggunaan faktor produksi bibit, pupuk kandang, pupuk Ammophos, pupuk NPK, pupuk KCL, pestisida Antracol, pestisida Gramoxone, dan tenaga kerja berpengaruh nyata terhadap produksi usahatani wortel di Desa Surbakti, Kecamatan Simpang Empat, Kabupaten Karo. Secara parsial (uji-t) bibit, pupuk kandang, pupuk Ammophos, pupuk NPK, pestisida Antracol, pestisida Gramoxone, dan tenaga kerja berpengaruh nyata terjadap produksi wortel, sedangkan pupuk KCL tidak berpengaruh nyata terhadap produksi wortel di daerah penelitian.

2. Penggunaan faktor produksi bibit, pupuk kandang, pupuk Ammophos, pupuk NPK, pupuk KCL, pestisida Antracol, pestisida Gramoxone, dan tenaga kerja belum mencapai titik optimum (belum efisien).

3. Pendapatan bersih petani wortel di daerah penelitian diperoleh sebesar $\mathrm{Rp}$ 27.763.882,28/hektar/musim tanam.

\section{DAFTAR PUSTAKA}

Agustin, IIW. 2017. “Analisis Efisiensi Alokatif Penggunaan Faktor-Faktot Produksi Usahatani Wortel (Daucus carota L.) (Studi Kasus Desa Ngabab, Kecamatan Pujon, Kabupaten Malang)." Skripsi. Universitas Brawijaya. Malang.

BPS Kabupaten Karo. 2018. Kabupaten Karo Dalam Angka 2018. Kabanjahe.

BPS Kabupaten Karo. 2018. Kecamatan Simpang Empat Dalam Angka 2018. Kabanjahe.

Devi, C, Satria, P. Utama, dan Reflis. 2007. "Analisis Efisiensi Usahatani Wortel (Daucus carota.L) dan Faktor-Faktor Sosial Ekonomi yang Mempengaruhi Pendapatan (Studi Kasus di Desa Suban Ayam Kecamatan Selupu Rejang
Kabupaten Rejang Lebong)." Thesis. Fakultas Pertanian Universitas Bengkulu.

Eko, A., A. Apri, dan B. Redy. 2017. "Analisis Pendapatan dan Pemasaran Usahatani Wortel (Daucus carota.L) di Desa Bengko Kecamatan Sindang Kabupaten Rejang Lebong. Thesis. Universitas Bengkulu.

Ghozali. 2001. Aplikasi Analisis Multivariete dengan Program SPSS. Penerbit Universitas Diponegoro. Semarang.

Rosadi, M. A. 2018. "Analisis Usahatani Wortel di Desa Ngabab Kecamatan Pujon Kabupaten Malang." Skripsi. Fakultas PertanianPeternakan. Universitas Muhammadiyah Malang. Malang.

Richard, R. 2018. Analisis Faktor Yang Mempengaruhi Produksi dan Pendapatan Usahatani Wortel. Skripsi. Program Studi Agribisnis. Universitas Katolik Santo Thomas. Sumatera Utara.

Rosihan, A. 2016. “Analisis Efisiensi Alokatif Penggunaan Faktor-Faktor Produksi Usahatani Wortel (Daucus carota L.) (Studi Kasus Desa Ngabab, Kecamatan Bumiaji, Kota Batu." Jurnal Agrise Universitas Brawijaya. http://agrise.ub.ac.id/index.php/agrise/article/vi ew/100/127.

Saragi, C.P.H. 1992. "Efesiensi Penggunaan FaktorFaktor Produksi Pada Perkebunan Kopi Di Desa Kabun Getas/Assinan/Banaran Pt Perkebunan XVIII." Tesis. Fakultas Pascasarjana Universitas Gadjah Mada. Yogyakarta.

Soekartawi. 2002. Analisis Usahatani. UI Press. Jakarta.

Supranto. 1994. Statistik Teori dan Aplikasi Jilid I Edisi Kelima. Penerbit Erlangga. Jakarta. 